\title{
Milking efficiency for grazing dairy cows can be improved by increasing automatic cluster remover thresholds without applying premilking stimulation
}

\author{
J. P. Edwards, ${ }^{*}{ }^{1}$ J. G. Jago, ${ }^{*}$ and N. Lopez-Villalobos $\dagger$ \\ *DairyNZ, Private Bag 3221, Hamilton 3240, New Zealand \\ †Institute of Veterinary, Animal and Biomedical Sciences, Massey University, Private Bag 11222, Palmerston North 4442, New Zealand
}

\begin{abstract}
It was hypothesized that streamlined premilking stimulation routines are effective at reducing cow cluster-on time but are not required to maintain milk yield or quality when increasing the automatic cluster remover (ACR) threshold above $0.4 \mathrm{~kg} / \mathrm{min}$. This was tested by examining the effect of 3 premilking treatments and 4 ACR thresholds over an 11-wk period with 96 mixed-age New Zealand Friesian-Jersey cross cows during peak lactation. Three premilking treatments were chosen: attach cluster immediately (control), attach cluster immediately and apply $30 \mathrm{~s}$ of mechanical stimulation (Stim), and remove 2 squirts of milk from each quarter and attach cluster (Strip). Four ACR milk flow rate thresholds were imposed: $0.2 \mathrm{~kg} /$ min (ACR2), $0.4 \mathrm{~kg} / \mathrm{min}$ (ACR4), $0.6 \mathrm{~kg} / \mathrm{min}$ (ACR6), and $0.8 \mathrm{~kg} / \mathrm{min}$ (ACR8). Measurements included individual cow milk yield, cluster-on time, average milk flow rate, maximum milk flow rate, time to average milk flow rate, time from maximum milk flow rate to end of milking, and the milk flow rate and cumulative yield at predetermined intervals during each milking session. Milk composition and somatic cell count (SCC) were determined on composite milk samples, collected weekly. Postmilking strip yield was measured at the end of each treatment period. Cows receiving the Strip treatment had a 3 to $4 \%$ shorter cluster-on time than did cows on the control treatment, but cows receiving Stim were not different from the control cows. Milk yield, SCC, and postmilking strip yield were not different between the 3 premilking treatments. Cluster-on time of the ACR8 cows was 18 to $26 \%$ less than that of the ACR2 cows, but SCC and milk production variables did not differ between the 4 end-of-milking treatments, despite higher strip yields as the ACR threshold increased. Increasing the ACR threshold is an effective strategy to improve milking efficiency (cows milked per operator per hour) in situations where the work
\end{abstract}

Received November 19, 2012.

Accepted February 26, 2013.

${ }^{1}$ Corresponding author: Paul.Edwards@dairynz.co.nz routine times of dairy operators can be accelerated. To achieve the greatest milking efficiency, clusters should be attached immediately without premilking manual or mechanical stimulation.

Key words: milking duration, stimulation, automatic cluster remover

\section{INTRODUCTION}

Herd sizes in pasture-based dairy farms have increased dramatically in recent decades, a trend that is likely to continue (O'Donovan et al., 2008; DAFF, 2010; DairyNZ and LIC, 2012). Herd expansion requires additional labor and often exerts pressure on existing resources. Annually, 33 to $57 \%$ of labor resources on pasture-based dairy farms are required for the milk harvesting process (O'Brien et al., 2004; Taylor et al., 2009). An efficient milk harvesting process is, therefore, important to successful expansion and management of large herds.

The cluster-on time of individual cows is an important factor determining herd milking times and thus labor requirements. It has been reported (Rasmussen, 1993; Burke and Jago, 2011) that the cluster-on time of cows can be reduced, without affecting milk yield and udder health indicators, by increasing the automatic cluster remover (ACR) threshold from 0.2 to $0.4 \mathrm{~kg} / \mathrm{min}$. A recent study with dairy cows in late lactation reported that ACR thresholds up to $0.8 \mathrm{~kg} / \mathrm{min}$ further reduced individual cluster-on times without affecting milk yield or indicators of udder health when using a milking routine with no premilking stimulation, as is common practice on pasture-based dairy farms (Edwards et al., 2013). However, higher postmilking milk residuals were reported with increasing ACR threshold; therefore, the consequences of applying these ACR thresholds in peak lactation, when milk yields are greater, requires examination.

Premilking stimulation has been reported to reduce cluster-on time despite using a genetic strain of cow in which prestimulation has not been commonplace since the 1970s (Phillips, 1987; Edwards et al., 2013). However, the time taken to apply premilking stimulation was greater than the reduction in cluster-on time, resulting 
in cows remaining in the dairy longer and additional labor being required. The requirement for additional labor could be eliminated and the prestimulation routine shortened if the latency period between stimulation and cluster attachment was removed from the routine. Recent research has indicated that a latency period between stimulation and cluster attachment provided no benefit to milk yield or cluster-on time when udder fill was greater than 40\% (Kaskous and Bruckmaier, 2011). Thus, if the time to cluster attachment can be reduced using premilking stimulation without a latency period, a net benefit to milking efficiency (cows milked per operator per hour) may be achieved without increasing labor requirements in some dairies.

Maximum throughput is achieved in many larger rotary dairies ( $>50$ bails) when rotation speeds are greater than $10 \mathrm{~s} /$ bail (Edwards et al., 2012). This speed does not allow sufficient time for a single operator to apply manual stimulation and attach clusters (Armstrong and Quick, 1986). Therefore, additional labor would be required to maintain this speed, even with the removal of the latency period, unless a form of mechanical stimulation was introduced. Likewise, in larger herringbone dairies ( $>18$ units), the addition of $\sim 10 \mathrm{~s} / \mathrm{cow}$ for stimulation during spring would reduce throughput unless labor was increased (O'Brien et al., 2012).

We hypothesized that streamlined premilking stimulation routines are effective at reducing cow cluster-on time but are not required to maintain milk yield or quality when increasing the ACR threshold above 0.4 $\mathrm{kg} / \mathrm{min}$. This was tested by examining the effect of 3 premilking treatments and 4 ACR thresholds on peaklactation dairy cows yielding, on average, $22.3 \mathrm{~kg} / \mathrm{d}$.

\section{MATERIALS AND METHODS}

\section{Animals}

The study was conducted using 96 mixed-age New Zealand Friesian-Jersey cross cows at the DairyNZ Lye Farm (Hamilton, New Zealand) from September to December 2011. Cows were representative of those present in pasture-based production systems and, therefore, had relatively low daily milk yields compared with those achieved by cows managed in mixed ration systems typical in North America and continental Europe. The use of animals was approved by the Ruakura Animal Ethics Committee. Cows were managed as one herd and rotationally grazed on predominantly perennial ryegrass pasture following the decision rules of Macdonald and Penno (1998). Milking of the herd occurred in the morning between 0700 and $0830 \mathrm{~h}$ and in the afternoon between 1500 and $1630 \mathrm{~h}$, through a 30-bail rotary dairy (GEA Farm Technologies GmbH, Bönen, Germany) with plant vacuum set at $42 \mathrm{kPa}$. Postmilking, a commercially available teat sanitizer (Teat-Guard Plus, Ecolab, St. Paul, MN) was applied manually to each cow by pressurized spray upon exit from the rotary platform.

\section{Experimental Design}

The experiment was arranged as a $3 \times 4$ factorial: 3 premilking treatments were applied across 4 ACR thresholds. Premilking treatments were as follows: clusters attached at the first bail after cows had walked onto the rotary platform (control); tactile stimulation applied by removing 2 squirts of foremilk from each quarter, requiring $\sim 10 \mathrm{~s}$, followed by immediate cluster attachment (Strip); and mechanical stimulation applied using StimoPuls Apex M (GEA) equipped clusters (Stim). The pulsator ratio was 70:30 with 300 cycles/ min (at half vacuum) during stimulation and 60:40 with 60 cycles/min during normal milking. Stimulation time set at $30 \mathrm{~s}$ was considered appropriate for cows with a high degree of udder fill, as expected during peak lactation (Weiss and Bruckmaier, 2005).

For each premilking strategy, 4 ACR thresholds were imposed by the herd management system: $0.2 \mathrm{~kg} / \mathrm{min}$ (ACR2), $0.4 \mathrm{~kg} / \mathrm{min}$ (ACR4), $0.6 \mathrm{~kg} / \mathrm{min}$ (ACR6), and $0.8 \mathrm{~kg} / \mathrm{min}$ (ACR8). If the cow's milk flow rate remained below the respective threshold level for longer than $4 \mathrm{~s}$, the ACR was activated and the cluster was removed within 5 s. Clusters remained attached for a minimum of $120 \mathrm{~s}$. All treatment groups were balanced for days in milk, cluster-on time, yield, SCC, breed, and age.

Covariate data were collected in wk 1 , when cows were milked using the control treatment with clusters attached at entry and the ACR threshold set at $0.35 \mathrm{~kg} /$ min. In wk 2, cows were transitioned to the new ACR threshold and remained on the allocated ACR threshold for the remainder of the experiment ( $9 \mathrm{wk}$ ). On the first day of wk 2, ACR2 and ACR4 cows were changed from $0.35 \mathrm{~kg} / \mathrm{min}$ to their respective thresholds. At the same time, cows on the ACR6 and ACR8 treatments were increased to $0.5 \mathrm{~kg} / \mathrm{min}$ and remained there for $3 \mathrm{~d}$ before changing to their final ACR thresholds of 0.6 and $0.8 \mathrm{~kg} / \mathrm{min}$. At the beginning of wk 3, the premilking treatments commenced and were applied for $3 \mathrm{wk}$ (period 1). At the start of wk 6, cows in each of the premilking treatment groups were randomized and split evenly into each of the other 2 treatments, which were applied for a further $3 \mathrm{wk}$ (period 2). At the start of wk 9, cows switched premilking treatments to the remaining treatment, which was applied for a final $3 \mathrm{wk}$ (period 3), so each cow was exposed to all 3 treatments. 


\section{Measurements}

The dairy was fitted with Metatron P21 milk meters (GEA) at each bail. The herd management software, DairyPlan (GEA), was set to record individual cow milk yield, cluster-on time (vacuum on to cluster off), average milk flow rate (from initiation of milk flow to cluster removal), maximum milk flow rate, time to average milk flow rate, and time from maximum milk flow rate to end of milking (decline duration). Additionally, average milk flow rate and cumulative yield were recorded in 15-s intervals up to $4 \mathrm{~min}$, over 30 -s intervals between 4 and $7 \mathrm{~min}$, and over 60-s intervals from 7 to 10 min for each cow at each milking session. Milk meter samples were collected weekly to determine composition (MilkoScan 133B Analyzer, Foss Electric, Hillerød, Denmark) and SCC using an automated cell counter (Fossomatic 5000, Foss Electric). At the end of each period, postmilking strip yield was measured by reattaching the cluster within 2 min of the end of milking. Downward pressure was applied until no further milk could be removed from the udder. Milk weight was recorded before and following cluster reattachment. Teat-end hyperkeratosis was assessed using the field evaluation method (Mein et al., 2001) during wk 1 and 11. Teat-ends were scored using a 1-4 scale, whereby teats classed as normal, smooth, rough, and very rough were assigned the scores $1,2,3$, and 4, respectively. At the last a.m. milking of wk 2 and on the last a.m. milking of each period, foremilk samples were collected aseptically from each quarter of all cows. Bacteria in the milk were identified using recommended procedures (NMC, 1999). A $10-\mu \mathrm{L}$ subsample from each quarter was streaked across 1 quadrant of an agar plate containing $5 \%$ sheep blood and $0.1 \%$ esculin (Fort Richard Laboratories, Otahuhu, Auckland, New Zealand) and incubated at $37^{\circ} \mathrm{C}$ for $48 \mathrm{~h}$. Identification of isolates was made on the basis of colony morphology, catalase test, patterns of hemolysis, esculin reaction, inulin fermentation, sodium hippurate reaction, Gram stain, growth in brain-heart infusion broth with $6.5 \%$ salt, and the Christie, Atkins, Munch-Petersen (CAMP) test. Gramnegative isolates were identified by lactose reaction, citrate utilization, motility development, oxidase reaction, and triple sugar iron slant reaction.

\section{Statistical Analysis}

Somatic cell count data were normalized using a $\log _{10}$ transformation, and strip yield data were normalized using a square root transformation. The milking data from d 6 to 19, normalized SCC, and strip yield data were analyzed using a mixed model that included the fixed effects of period, session (a.m./p.m.), ACR thresh- old, premilking treatment, interaction between ACR threshold and premilking treatment, and initial milking characteristics as covariables plus the random effect of cow within each period. Average milk flow profiles were derived from least squares means of the average milk flow rate during each of the recorded time intervals. A milk flow curve was defined as bimodal if during the first $75 \mathrm{~s}$ the milk flow rate decreased by more than $0.1 \mathrm{~kg} / \mathrm{min}$ from one 15 -s time interval to the next, the milk flow rate during the second and third time intervals after this interval either remained the same or increased, and the milk flow rate thereafter was greater than zero. All analyses were undertaken using GenStat 14.1 (VSN International, Hemel Hampstead, UK).

\section{RESULTS}

\section{Premilking Treatment}

Milk yield and composition were not affected by premilking treatment and no interaction with ACR threshold was detected for any milk production variable. The average herd milk yield was $22.3 \mathrm{~kg} / \mathrm{d}$, composed of 0.9 $\mathrm{kg}$ of fat $/ \mathrm{d}, 0.8 \mathrm{~kg}$ of protein/d, and $1.1 \mathrm{~kg}$ of lactose $/ \mathrm{d}$. The statistical significance of milking characteristics was similar at a.m. and p.m. milkings. Cows receiving the Strip treatment had a shorter cluster-on time than those on the control treatment $(P<0.001$; Table 1$)$, with the scale of the reduction similar at the a.m. and p.m. sessions, at 13 and $11 \mathrm{~s}$, respectively (3-4\%). In contrast, mechanical stimulation (Stim) provided no benefit in reducing cluster-on time compared with the control at both a.m. and p.m. milkings. Cows on the Strip treatment had a greater average milk flow rate $(P$ $<0.001$ ), shorter time from cluster attachment to average milk flow rate $(P<0.001)$, and greater maximum milk flow rate $(P<0.001)$. However, no differences in decline duration were detected between premilking treatments. Differences and similarities in the daily average milk flow curves of the 3 treatments can be observed in Figure 1. Examining the average milk flow curves, no premilking treatment, including the control, had a bimodal milk flow curve (Figure 1), although a percentage of cows at any given milking had bimodal curves (Table 1). Furthermore, no differences in SCC, strip yield, or interaction between these measures and ACR threshold were detected.

\section{ACR Thresholds}

Cluster-on time decreased by 18 to $26 \%$ with increasing ACR threshold, for ACR2 and ACR8 treatments ( $P$ $<0.001$; Table 2). No differences were detected in milk yield, milk composition, SCC, or teat hyperkeratosis 


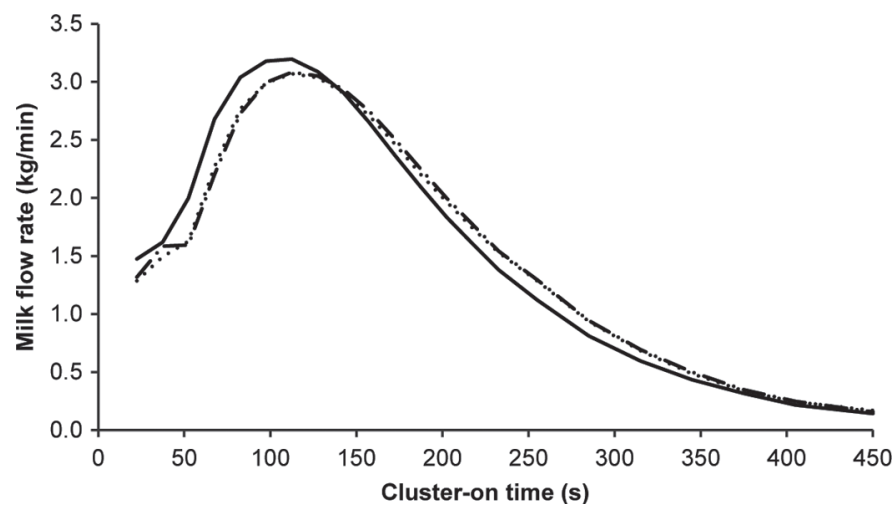

Figure 1. Average daily milk flow curves (average of a.m. and p.m. sessions) for 3 premilking treatments: control ( $\cdots$; attach cluster immediately), Stim (--; attach cluster immediately and apply $30 \mathrm{~s}$ of mechanical stimulation), and Strip (-; 2-squirt strip from each quarter and attach cluster).

score. Only 5 cows developed a new infection by Corynebacterium bovis or CNS during the experiment. Average milk flow rate increased with higher ACR threshold $(P<0.001)$. However, time to average flow, maximum milk flow rate (a.m. only), or milk harvested did not differ in the first 2 min (a.m. only). Decline duration (the time from maximum milk flow rate to the end of milking) decreased with increasing ACR threshold ( $P$ $<0.001$ ). The statistical significance of milking characteristics and shape of the average milk flow curves were similar at a.m. and p.m. milkings; therefore, daily averages were used to produce Figure 2. Cumulative yield was greater $(P<0.05)$ between 135 and $240 \mathrm{~s}$ of milking for higher ACR thresholds (Figure 2). Average milk flow rate during early milking, 30 to $45 \mathrm{~s}$, and near peak milk flow, 120 to $135 \mathrm{~s}$, was greater $(P<0.05)$ for higher ACR thresholds (Figure 2). Strip yield increased with higher ACR threshold (Table 2).

\section{DISCUSSION}

Our data support the hypothesis that premilking stimulation is not required to maintain milk production when utilizing ACR thresholds greater than 0.4 $\mathrm{kg} / \mathrm{min}$ because no interaction was detected between premilking treatment and ACR threshold for any milk production variable or indicator of udder health using cows typical of a pasture-based production system. Furthermore, a higher ACR threshold reduced cluster-on time without compromising milk production, a result

Table 1. Effect of 3 premilking treatments (control, Stim, and Strip) on milking characteristics, SCC, and strip yield

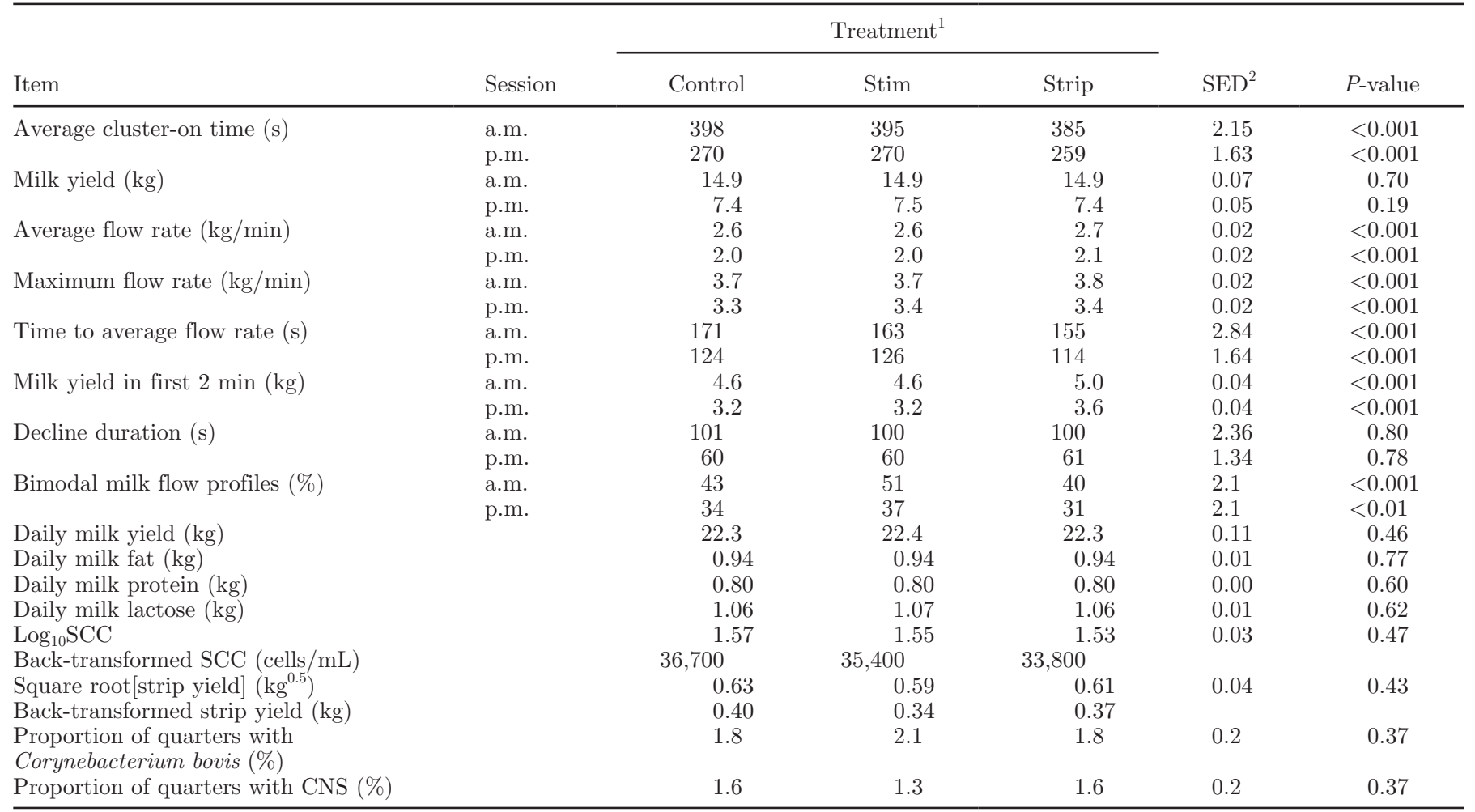

${ }^{1}$ Control $=$ attach cluster immediately, Stim $=$ attach cluster, $30 \mathrm{~s}$ of mechanical stimulation applied, and Strip $=2$-squirt strip from each quarter and attach cluster.

${ }^{2}$ Standard error of the difference. 


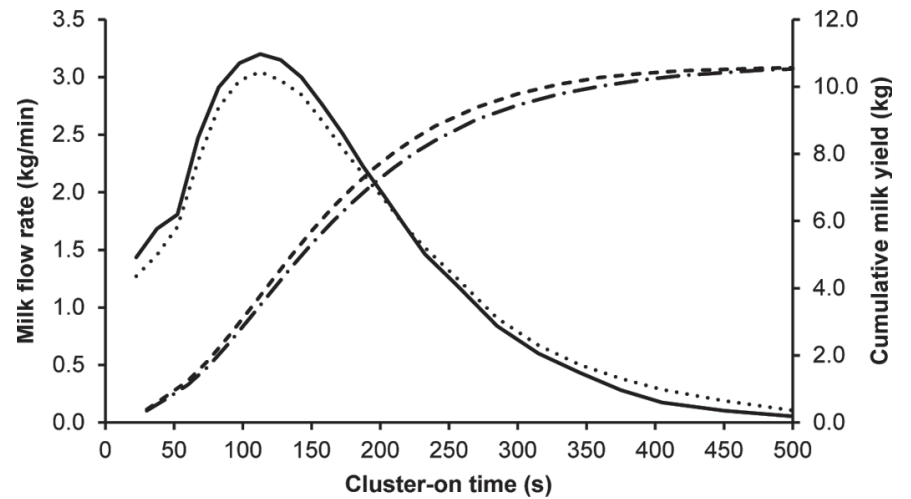

Figure 2. Average daily milk flow curves (average of a.m. and p.m. sessions) for 2 automatic cluster remover thresholds: ACR2 (-; cluster removed at $0.2 \mathrm{~kg} / \mathrm{min}$ ) and $\mathrm{ACR} 8(\cdots$; cluster removed at $0.8 \mathrm{~kg} / \mathrm{min})$ and average cumulative yield curves for ACR2 $(-\cdot)$ and $\operatorname{ACR} 8(--)$.

consistent with that reported for cows in late lactation (Edwards et al., 2013).

The streamlined premilking treatment, without a latency period (Strip), was effective at reducing cluster-on time during peak lactation. Compared with the
Strip treatment, mechanical stimulation in the form of the Stim treatment provided no advantage to milking efficiency over attaching clusters with no premilking preparation. Similarly, Weiss and Bruckmaier (2005) reported no decrease in total milking time using between zero and $90 \mathrm{~s}$ of mechanical stimulation. Neither form of stimulation provided an advantage to milk yield, composition, or milk quality/udder health. The Strip treatment reduced the time that clusters were attached on average by $12 \mathrm{~s}$, slightly less than the average 19 s reported by Edwards et al. (2013) using dairy cows in late lactation. However, the effect of stimulation was expected to be less in peak lactation (Bruckmaier and Hilger, 2001). The similar reduction in cluster-on time recorded between peak and late lactation, the former without a latency period, lends support to the results of Kaskous and Bruckmaier (2011), who reported no effect of latency period when udder fill was greater than $40 \%$. The reduction in cluster-on time of cows on the Strip treatment was achieved through greater average milk flow rates, particularly before maximum milk flow rate, where time to average milk flow rate was less and a greater amount of milk was harvested in the

Table 2. Effect of 4 automatic cluster remover thresholds (ACR2, ACR4, ACR6, and ACR8) on milking characteristics, SCC, strip yield, and teat-end hyperkeratosis score

\begin{tabular}{|c|c|c|c|c|c|c|c|}
\hline Variable & Session & \multicolumn{4}{|c|}{ Treatment $^{1}$} & $\mathrm{SED}^{2}$ & $P$-value \\
\hline Average cluster-on time (s) & a.m. & 434 & 394 & 386 & 356 & 10.51 & $<0.001$ \\
\hline \multirow[t]{2}{*}{ Milk yield (kg) } & a.m. & 15.0 & 14.9 & 14.8 & 14.9 & 0.26 & 0.83 \\
\hline & p.m. & 7.4 & 7.6 & 7.4 & 7.3 & 0.20 & 0.63 \\
\hline Average flow rate $(\mathrm{kg} / \mathrm{min})$ & a.m. & 2.5 & 2.6 & 2.6 & 2.8 & 0.07 & $<0.001$ \\
\hline Maximum flow rate $(\mathrm{kg} / \mathrm{min})$ & p.m. & 3.2 & 3.4 & 3.4 & 3.4 & 0.08 & $<0.05$ \\
\hline \multirow[t]{2}{*}{ Time to average flow rate $(\mathrm{s})$} & a.m. & 171 & 161 & 162 & 159 & 9.30 & 0.60 \\
\hline & p.m. & 122 & 123 & 122 & 119 & 4.38 & 0.81 \\
\hline \multirow[t]{2}{*}{ Milk yield in first $2 \min (\mathrm{kg})$} & a.m. & 4.7 & 4.7 & 4.7 & 4.9 & 0.14 & 0.33 \\
\hline & p.m. & 3.1 & 3.3 & 3.4 & 3.4 & 0.13 & $<0.05$ \\
\hline \multirow[t]{2}{*}{ Decline duration (s) } & a.m. & 121 & 106 & 97 & 78 & 7.85 & $<0.001$ \\
\hline & p.m. & 85 & 60 & 51 & 45 & 5.48 & $<0.001$ \\
\hline Daily milk lactose (kg) & & 1.05 & 1.07 & 1.06 & 1.05 & 0.02 & 0.69 \\
\hline $\log _{10} \mathrm{SCC}$ & & 1.59 & 1.52 & 1.54 & 1.55 & 0.05 & 0.55 \\
\hline Back-transformed SCC (cells/mL) & & 38,600 & 33,000 & 34,200 & 35,600 & & \\
\hline Square root[strip yield] $\left(\mathrm{kg}^{0.5}\right)$ & & 0.52 & 0.52 & 0.64 & 0.75 & 0.08 & $<0.05$ \\
\hline Back-transformed strip yield $(\mathrm{kg})$ & & 0.27 & 0.27 & 0.41 & 0.57 & & \\
\hline Proportion of quarters with & & 2.1 & 1.4 & 4.2 & 0.0 & 2.4 & 0.38 \\
\hline Corynebacterium bovis (\%) & & & & & & & \\
\hline Proportion of quarters with CNS (\%) & & 1.0 & 1.7 & 3.1 & 0.0 & 1.7 & 0.30 \\
\hline Teat-end hyperkeratosis score ${ }^{3}$ & & 2.4 & 2.3 & 2.3 & 2.2 & 0.14 & 0.81 \\
\hline
\end{tabular}

${ }^{1}$ Cluster was removed after milk flow rate was less than 0.2 (ACR2), 0.4 (ACR4), 0.6 (ACR6), and 0.8 (ACR8) kg/min.

${ }^{2}$ Standard error of the difference.

${ }^{3}$ Assessed using the field evaluation method (Mein et al., 2001). 
first 2 min. Additionally, a greater maximum milk flow rate was recorded for Strip cows, a result also reported by Bruckmaier and Blum (1996) using cows at mixed stages of lactation, although the same effect was not reported by Edwards et al. (2013) using cows in late lactation. Post-peak milk flow, the decline duration was not different between premilking treatments, and thus, overall, Strip cows achieved a greater average milk flow rate and a shorter cluster-on time.

The Strip treatment provided little advantage to milking efficiency despite the reduction in cluster-on time. Cluster-on time was reduced by $12 \mathrm{~s}$, and the removal of a latency period from the routine allowed it to be applied without increasing labor requirements; however, $\sim 10$ s was required for stimulation so it provided little net benefit to the time from the cow entering the dairy to cluster removal. Thus, the Strip treatment was an improvement from the routine used by Edwards et al. (2013) and could comply with European Union legislation that requires milk from each animal to be checked for organoleptic or physicochemical abnormalities by the milker (European Union, 2004). However, the Strip treatment would not comply with the Pasteurized Milk Ordinance (DHHS-PHS-FDA, 2009), which requires teats to be treated with a sanitizing solution and wiped dry. Furthermore, adding $10 \mathrm{~s}$ to the work routine of the operator attaching clusters reduces the maximum number of cows that can be milked per hour unless additional labor is added (Edwards et al., 2012; O'Brien et al., 2012). This result may be in contrast to that experienced in the United States, where conflicting evidence has been reported as to the effect of premilking preparation on overall dairy performance (Eicker et al., 2000; Armstrong et al., 2001). Differences may exist due to a greater response to stimulation, reportedly around $60 \mathrm{~s}$ (Sagi et al., 1980), or greater average milk flow rates compared with those reported here (Watters et al., 2012). Additionally, in housed systems, such as are common in the United States, premilking routines are of greater importance to comply with milk hygiene regulations (DHHS-PHS-FDA, 2009). In the present scenario, if no labor is added, increasing the work routine time would increase the rotation time in rotary dairies or row time in herringbone dairies, thereby reducing potential throughput but also increasing overmilking (clusters remaining attached after the cessation of milk flow) in dairies not fitted with ACR. In these dairies, overmilking would be exacerbated by the premilking stimulation increasing average milk flow rate, and thus reducing the time required to harvest milk, while increasing cluster-on time through the longer rotation or row times. Ideally, decreasing cluster-on time without increasing work routine time would have been achieved using mechanical stimulation; however, cluster-on time was not significantly shorter for the Stim treatment compared with the control. Thus, neither premilking treatment appears effective at improving milking efficiency in herds typically found in pasture-based production systems; to achieve maximum efficiency, clusters should be attached immediately after entering the bail to improve utilization, a conclusion supported by Edwards et al. (2013).

Compared with strategies involving premilking stimulation, increasing the ACR threshold above $0.4 \mathrm{~kg} /$ min appeared to provide significant benefits to milking efficiency without the need for premilking stimulation. Increasing the ACR threshold to $0.4,0.6$, and $0.8 \mathrm{~kg} /$ min provided a daily average 12,15 , and $21 \%$ reduction in cluster-on time compared with the New Zealand standard of $0.2 \mathrm{~kg} / \mathrm{min}$, without negatively affecting milk production or composition or indicators of udder health. Correspondingly, the recorded increase in average milk flow rate with increasing ACR threshold was logical, in part due to the cluster being removed earlier, thereby reducing the time of low milk flow rate near the end of milking and mathematically increasing average milk flow rate. The reduction in the duration of low milk flow rate at the end of milking is confirmed by the decreasing decline duration with increasing ACR threshold. However, milk flow rate must have also physically increased to maintain milk production with reduced cluster-on times, because the shortening of the decline duration accounted for only 39 to $55 \%$ of the total reduction in cluster-on time. The physical increase in average milk flow rate could be explained by small differences in milk flow curve and cumulative yield curve between the treatments (Figure 2). The greater average cumulative yield of ACR8 cows compared with ACR 2 cows from $135 \mathrm{~s}$ through $240 \mathrm{~s}$ of milking indicates greater average milk flow between these points. The milk flow curves and cluster-on times of individual cows varied greatly; however, the average flow curves of the ACR2 and ACR 8 cows indicated small but significant differences. The ACR8 cows reached a statistically greater average milk flow rate in early milking for the period 30 to $45 \mathrm{~s}$ and near the peak period of 120 to $135 \mathrm{~s}$; however, it should be noted that, unlike with the premilking treatments, ACR treatments were not applied in a crossover design. The greater average milk flow recorded in early milking may be the result of greater cisternal milk volume, which can be rapidly evacuated from the udder after cluster attachment (Bruckmaier, 2001). Greater cisternal milk could be present due to residual milk from the previous milking, which increased with increasing ACR threshold due to the cluster being removed earlier (Edwards et al., 2013). Residual milk is reabsorbed by the alveolar compartment immediately after milking (Knight et al., 1994; 
Caja et al., 2004); however, a small amount of newly secreted milk moves back to the cistern within the first $6 \mathrm{~h}$ postmilking (Stelwagen et al., 1996). Additionally, Knight et al. (1994) reported that the movement of milk to the cistern occurs in 2 distinct stages, the first being soon after milking. Greater residual milk in the alveolar compartment could increase the availability of milk to be transferred during this time and may therefore increase the rate of movement back to the cistern, potentially resulting in greater cisternal volume at the next milking (Pfeilsticker et al., 1996). It is likely that greater cisternal milk would generate a higher baseline intramammary pressure (Pfeilsticker et al., 1995), resulting in an increased milk flow rate. Thus, a potential explanation is provided for the greater average milk flow rate recorded with higher ACR thresholds.

Increasing ACR threshold had no effect on indicators of udder health despite greater residual milk due to earlier removal of the cluster. Residual strip yield increased by $0.3 \mathrm{~kg}$ from ACR2 to ACR8, whereas SCC remained unchanged. Interestingly, the strip yields of the ACR2 and ACR4 treatments were similar, a result also reported by Edwards et al. (2013) but not reported during peak lactation in previous studies (Jago et al., 2010a; Burke and Jago, 2011). The presence of residual milk is thought by many farmers to be linked with mastitis; however, increasing evidence from the current and previous studies (some longer term) indicates that an increase in residual milk does not adversely affect SCC or rates of clinical mastitis (Clarke et al., 2008; Jago et al., 2010b; Burke and Jago, 2011; Edwards et al., 2013). Thus, increasing the ACR threshold does not appear to adversely affect udder health.

Increasing the ACR threshold can be implemented on many farms to improve milking efficiency and decrease herd milking times. Decreasing individual cow cluster-on time allows more cows to be milked and milk harvested per hour (Edwards et al., 2012). However, to take the greatest advantage of this reduction, a decrease in rotation time for rotary or row time for herringbone dairies is required. It should be noted, however, that row time in the herringbone is limited by the slowest milking cow, so increasing the ACR threshold may not result in decreased row times (Stewart et al., 2002). To facilitate the decrease in row or rotation time, a corresponding decrease in the work routine time of the operator attaching clusters must occur. For example, if moving from ACR2 to ACR8 in a 60-bail rotary, work routine time needs to be reduced, and thus platform speed increased, by $1.3 \mathrm{~s} /$ bail, or in a 20-unit herringbone dairy, by $4 \mathrm{~s} / \mathrm{cow}$, to achieve the approximately 80 -s decrease in rotation or row time. A change of this magnitude should be achievable on many farms, particularly those with rotary dairies having $<60$ bails
(Edwards et al., 2012), or herringbone dairies with $<26$ units during peak lactation (O'Brien et al., 2012). Thus, increasing the ACR threshold to improve milking efficiency is a strategy that can be implemented on many farms.

\section{CONCLUSIONS}

Increasing the ACR threshold is an effective strategy to improve milking efficiency in situations where work routine times can be accelerated. The increased average milk flow rate recorded with higher ACR thresholds may be a result of a greater volume of cisternal milk. The mechanical stimulation treatment chosen was not effective at replacing manual stimulation, and neither premilking treatment appeared to provide an advantage to milking efficiency in pasture-based systems. Manual stimulation decreases the number of cows able to be milked per hour unless labor is added and it may cause increased overmilking in dairies not fitted with ACR. Consequently, to achieve the greatest milking efficiency in pasture-based systems, clusters should be attached immediately without premilking preparation.

\section{ACKNOWLEDGMENTS}

This study was part of a program of research funded by DairyNZ Inc. (Hamilton, New Zealand). The authors acknowledge DairyNZ Lye Farm (Hamilton, New Zealand) staff for animal management and milking, the Newstead technical team, in particular Jennie Burke (DairyNZ), for support with data collection and Barbara Dow (DairyNZ) for assistance with the data analysis.

\section{REFERENCES}

Armstrong, D. V., M. J. Gamroth, and J. F. Smith. 2001. Milking parlour performance. Proc. West. Dairy Manage. Conf. 5:7-12.

Armstrong, D. V., and A. J. Quick. 1986. Time and motion to measure milking parlour performance. J. Dairy Sci. 69:1169-1177. http:// dx.doi.org/10.3168/jds.S0022-0302(86)80518-5.

Bruckmaier, R. M. 2001. Milk ejection during machine milking in dairy cows. Livest. Prod. Sci. 70:121-124. http://dx.doi.org/10.1016/ S0301-6226(01)00204-4.

Bruckmaier, R. M., and J. W. Blum. 1996. Simultaneous recording of oxytocin release, milk ejection and milk flow during milking of dairy cows with and without prestimulation. J. Dairy Res. 63:201-208. http://dx.doi.org/10.1017/S0022029900031708.

Bruckmaier, R. M., and M. Hilger. 2001. Milk ejection in dairy cows at different degrees of udder filling. J. Dairy Res. 68:369-376. http://dx.doi.org/10.1017/S0022029901005015.

Burke, J. K., and J. G. Jago. 2011. Comparing somatic cell counts, production and milking durations of dairy cows when milked at two automatic cup removal flow-rate thresholds. Anim. Prod. Sci. 51:920-924. http://dx.doi.org/10.1071/AN11042.

Caja, G., M. Ayadi, and C. H. Knight. 2004. Changes in cisternal compartment based on stage of lactation and time since milk ejection in the udder of dairy cows. J. Dairy Sci. 87:2409-2415. http:// dx.doi.org/10.3168/jds.S0022-0302(04)73363-9. 
Clarke, T., E. M. Cuthbertson, R. K. Greenall, M. C. Hannah, and D. Shoesmith. 2008. Incomplete milking has no detectable effect on somatic cell count but increased cell count appears to increase strip yield. Aust. J. Exp. Agric. 48:1161-1167. http://dx.doi. org/10.1071/EA07259.

DAFF. 2010. Food Harvest 2020: A vision for Irish agri-food and fisheries. Department of Agriculture, Fisheries and Food (DAFF), Dublin, Ireland. http://www.agriculture.gov.ie/media/migration/ agri-foodindustry/foodharvest2020/2020FoodHarvestEng240810. pdf.

DairyNZ and LIC. 2012. New Zealand dairy statistics 2011-12. DairyNZ, Hamilton, New Zealand. http://www.dairynz.co.nz/file/ fileid/45159.

DHHS-PHS-FDA (Department of Health and Human Services, Public Health Service, and Food and Drug Administration). 2009. Item 13r Milking: Flanks, udders and teats. Pages 47-48 in Grade "A" Pasteurized Milk Ordinance. DHHS, PHS, and FDA, Washington, DC.

Edwards, J. P., J. G. Jago, and N. Lopez-Villalobos. 2013. Short-term application of pre-stimulation and increased automatic cluster remover threshold affect milking characteristics of grazing dairy cows in late lactation. J. Dairy Sci. 96:1886-1893. http://dx.doi. org/10.3168/jds.2012-6191.

Edwards, J. P., N. Lopez-Villalobos, and J. G. Jago. 2012. Increasing platform speed and the percentage of cows completing a second rotation improves throughput in rotary dairies. Anim. Prod. Sci. 52:969-973. http://dx.doi.org/10.1071/AN12071.

Eicker, S., S. Stewart, D. Reid, and P. Rapnicki. 2000. New tools for measuring the effect of stimulation and take-off on milk flows. Pages 127-133 in Proc. National Mastitis Counc. Annu. Mtg. National Mastitis Council, Madison, WI.

European Union. 2004. Laying down specific hygiene rules for food of animal origin: Hygiene during milking, collection and transport. Annex III, Section IX, Chapter I, Part II, Subpart B, Point 1(b) of Regulation (EC) No. 853/2004. Off. J. L 226:22-82.

Jago, J. G., J. K. Burke, and J. H. Williamson. 2010a. Effect of automatic cluster remover settings on production, udder health, and milking duration. J. Dairy Sci. 93:2541-2549. http://dx.doi. org/10.3168/jds.2009-2949.

Jago, J. G., J. E. McGowan, and J. H. Williamson. 2010b. Effect of setting a maximum milking time, from peak lactation, on production, milking time and udder health. N. Z. Vet. J. 58:246-252. http://dx.doi.org/10.1080/00480169.2010.69298.

Kaskous, S., and R. M. Bruckmaier. 2011. Best combination of prestimulation and latency period duration before cluster attachment for efficient oxytocin release and milk ejection in cows with low to high udder-filling levels. J. Dairy Res. 78:97-104. http://dx.doi. org/10.1017/S0022029910000816.

Knight, C. H., D. Hirst, and R. J. Dewhurst. 1994. Milk accumulation and distribution in the bovine udder during the interval between milkings. J. Dairy Res. 61:167-177. http://dx.doi.org/10.1017/ S0022029900028181

Macdonald, K. A., and J. W. Penno. 1998. Management decision rules to optimise milksolid production on dairy farms. Proc. N. Z. Soc. Anim. Prod. 58:132-135.

Mein, G. A., F. Neijenhuis, W. F. Morgan, D. J. Reinemann, J. E. Hillerton, J. R. Baines, I. Ohnstad, M. D. Rasmussen, L. Timms, J. S.
Britt, R. Farnsworth, N. Cook, and T. Hemling. 2001. Evaluation of bovine teat condition in commercial dairy herds. Pages 347-351 in Proc. 2nd Int. Symp. Mastitis and Milk Quality, Vancouver, Canada. National Mastitis Council, Madison, WI.

NMC. 1999. Laboratory Handbook on Bovine Mastitis. National Mastitis Council, Madison, WI

O'Brien, B., D. Gleeson, and K. O'Donovan. 2004. Labour expenditure on the milking process. Int. Dairy Topics 3:9-10.

O'Brien, B., J. G. Jago, J. P. Edwards, N. Lopez-Villalobos, and F. McCoy. 2012. Milking parlour size, premilking routine and stage of lactation affect efficiency of milking in single-operator herringbone parlours. J. Dairy Res. 79:216-223. http://dx.doi.org/10.1017/ S0022029912000088.

O'Donovan, K., B. O'Brien, D. J. Ruane, J. Kinsella, and D. Gleeson. 2008. Labour input on Irish dairy farms and the effect of scale and seasonality. J. Farm Manage. 13:327-342.

Pfeilsticker, H. U., R. Bruckmaier, and J. W. Blum. 1996. Cisternal milk in the dairy cow during lactation and after preceding teat stimulation. J. Dairy Res. 63:509-515. http://dx.doi.org/10.1017/ S0022029900032040.

Pfeilsticker, H. U., R. M. Bruckmaier, and J. W. Blum. 1995. Interruption of machine milking in dairy cows: Effects on intramammary pressure and milking characteristics. J. Dairy Res. 62:559-566. http://dx.doi.org/10.1017/S0022029900031289.

Phillips, D. S. M. 1987. Long-term change in yield response to premilking preparation. N. Z. J. Agric. Res. 30:317-323. http://dx.doi org $/ 10.1080 / 00288233.1987 .10421890$.

Rasmussen, M. D. 1993. Influence of switch-level of automatic cluster removers on milking performance and udder health. J. Dairy Res. 60:287-297. http://dx.doi.org/10.1017/S0022029900027631.

Sagi, R., R. C. Gorewit, W. G. Merrill, and D. B. Wilson. 1980. Premilking stimulation effects on milking performance and oxytocin and prolactin release in cows. J. Dairy Sci. 63:800-806. http:// dx.doi.org/10.3168/jds.S0022-0302(80)83009-8.

Stelwagen, K., C. H. Knight, V. C. Farr, S. R. Davis, C. G. Prosser, and T. B. McFadden. 1996. Continuous versus single drainage of milk from the bovine mammary gland during a 24 hour period. Exp. Physiol. 81:141-149.

Stewart, S., S. Godden, P. Rapnicki, D. Reid, A. Johnson, and S. Eicker. 2002. Effects of automatic cluster remover settings on average milking duration, milk flow, and milk yield. J. Dairy Sci. 85:818823. http://dx.doi.org/10.3168/jds.S0022-0302(02)74141-6.

Taylor, G., L. van der Sande, and R. Douglas. 2009. Smarter not harder: Improving labour productivity in the primary sector. DairyNZ, Hamilton, New Zealand. http://maxa.maf.govt.nz/sff/aboutprojects/search/05-028/technical-report.pdf.

Watters, R. D., N. Schuring, H. N. Erb, Y. H. Schukken, and D. M. Galton. 2012. The effect of premilking udder preparation on Holstein cows milked 3 times daily. J. Dairy Sci. 95:1170-1176. http://dx.doi.org/10.3168/jds.2011-4388.

Weiss, D., and R. M. Bruckmaier. 2005. Optimization of individual prestimulation in dairy cows. J. Dairy Sci. 88:137-147. http:// dx.doi.org/10.3168/jds.S0022-0302(05)72671-0. 